\title{
What Do the Midwives and Nurses Know About Safe Sleep?
}

\section{Ebe ve Hemșireler Güvenli Uyku Hakkında Ne Biliyor?}

\author{
(1) Illknur Yıldız
}

Sivas Cumhuriyet University Faculty of Health Sciences, Department of Pediatric Nursing, Sivas, Turkey

\begin{abstract}
Objective: Information and recommendations provided by midwives and nurses, who play a vital role in maternal and child health, about safe sleeping environment have an influence on the parents. This study aimed to determine the knowledge and opinions of midwives and nurses about safe sleeping environment.

Materials and Methods: This is a descriptive, cross-sectional study conducted on 220 midwives and nurses who worked at 18 family health centres and 2 hospitals. Data were collected using a descriptive characteristics form and safe sleep information form. The collected data were expressed as numbers, percentages, and mean and standard deviation values. Chi-square test was used to analyse the data.

Results: The mean age of the participants was $31.83 \pm 7.63$ years, $58.2 \%$ had a bachelor's degree and $56.8 \%$ were working at a hospital. Of all the participants, $90 \%$ stated that a non-supine position was the safest sleeping position since the supine position involved possible risk of choking. Furthermore, $83.2 \%$ of the participants stated that they had heard about Sudden Infant Death syndrome, $75.5 \%$ indicated that this syndrome was associated with the sleeping environment of babies and $62.3 \%$ specified that they informed families about safe sleep. The number of nurses who informed families about safe sleep was higher than those who had a bachelor's degree $(p<0.05)$.

Conclusion: Most midwives and nurses did not recommend the supine position, and they were aware of the risk factors such as bedsharing, placing soft objects on beds and using pillows. We recommend increasing awareness about safe sleep among midwives and nurses and providing them with appropriate training on safe sleeping environment. Keywords: Midwife, nurse, safe sleep, information
\end{abstract}

Öz

Amaç: Anne ve bebek sağlığına ilişkin önemli rolleri olan ebe ve hemşirelerin güvenli uyku ortamı hakkındaki bilgi ve önerileri ebeveynleri etkiler. Bu çalışma ebe ve hemşirelerin güvenli uyku ortamına ilişkin bilgi ve görüşlerini belirlemek amacıyla yapılmıştır.

Gereç ve Yöntem: Tanımlayıcı kesitsel tipteki çalışmaya 2 hastane ve 18 aile sağlığı merkezinde çalışan 220 ebe ve hemşire katılmıştır. Veriler tanıtıcı özellikler formu ve güvenli uyku bilgi formu ile toplanmış; sayı, yüzde, ortalama, standart sapma ve ki-kare analizi ile gösterilmiştir. Bulgular: Ebe ve hemşirelerin yaş ortalamaları $31,83 \pm 7,63$ olup, $\% 97,7^{\prime}$ si kadın, \%58,2'si lisans mezunu, \%56,8'i hastanede çalışmaktadır. Ebe ve hemşirelerin \%90'ı boğulmaya yol açabileceğini belirterek sırtüstü olmayan pozisyonu en güvenli uyku pozisyonu olarak tanımlamıştır. Katılımcıların \%83,2'si Ani Bebek Ölüm sendromunu duyduğunu, $\% 75,5^{\prime}$ i bebeğin uyku ortamı ile ilişkili olduğunu, \%62,3'ü güvenli uyku hakkında ailelere bilgi verdiğini ifade etmiştir. Güvenli uyku hakkında bilgi vermenin lisans mezunu hemşirelerde daha yüksek oranda olduğu belirlenmiştir $(p<0,05)$.

Sonuç: Ebe ve hemşirelerin çoğunluğunun sırtüstü pozisyonu önermediği ancak yatak paylaşımı, yatağa yumuşak nesne konulması ve yastık kullanımı gibi risk faktörlerine yönelik bilgi sahibi oldukları belirlenmiştir. Güvenli uyku konusunda ebe ve hemşirelerin farkındalıklarının artırıması ve eğitilmesi önerilebilir.

Anahtar Kelimeler: Ebe, hemşire, güvenli uyku, bilgi

\section{Introduction}

Sudden Infant Death syndrome (SIDS), the most common type of sudden unexpected infant death, is defined as the sudden and unexpected death of a healthy baby aged 1 month to 1 year (1). In the United States, nearly 3500 babies die each year due to sleep-related causes, including SIDS (2). Although data on the prevalence of SIDS in Turkey are limited, it has been reported that the incidence rate of infant deaths in 2017 was $9.1 \%$, with $1.5 \%$ of these being associated with SIDS (3).

"Healthy people 2020" objectives aim to reduce the rate of SIDS by $10 \%$ (4). The American Academy of Pediatrics (AAP)

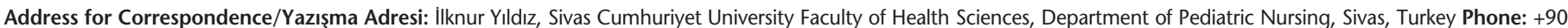
3462192504 E-mail: ilknuryildiz@yahoo.com.tr ORCID-ID: orcid.org/0000-0002-2574-7018 Received/Geliş Tarihi: 09.10.2020 Accepted/Kabul Tarihi: 14.01.2021

${ }^{\circ}$ Copyright 2021 by Turkish Sleep Medicine Society / Journal of Turkish Sleep Medicine published by Galenos Publishing House. 
has established recommendations for sleeping positions and environment of babies to reduce the rate of sudden sleeprelated infant deaths, including SIDS. These recommendations are as follows: use the supine sleeping position, use a firm sleeping surface, avoid placing soft objects in the crib, do not share bed, use a pacifier, do not expose the baby to cigarette smoke, and continue breastfeeding. In addition, it is recommended that healthcare providers, neonatal nurses, and other caregivers support the recommendations on reducing the risk of SIDS and serve as role models. Previous studies have shown that parents listen to and adopt the recommendations of healthcare personnel about safe sleep; however, healthcare professionals do not have a complete knowledge of the issue (5-12). In a limited number of studies conducted in Turkey, it has been found that healthcare professionals do not have adequate knowledge about safe sleep, particularly about safe sleeping positions $(13,14)$.

Midwives and nurses working at family health centers or pediatric clinics are important sources of information on infant care for parents. It has been reported that parents/babysitters practice the recommendations of healthcare professionals about safe sleep. In particular, the midwives and nurses working in the relevant field should determine the risk factors concerning a safe sleeping environment, serve as a role model, and provide counseling at each encounter with parents $(7,9,10,15)$. In Turkey, training on safe sleep is not provided at hospitals or family health centers, and there are no regulations regarding such trainings. Therefore, we believe that the results of this study will reveal the current knowledge about safe sleeping environment among midwives and nurses and will contribute to the execution of necessary actions in this field (such as adding this subject to the scope of routine neonatal follow-up or discharge training).

This study aimed to determine the knowledge and opinions of midwives and nurses about a safe sleeping environment. The study is expected to answer the following questions:

1. What do midwives and nurses know and think about a safe sleeping environment?

2. What are the factors that affect the knowledge and opinions of midwives and nurses about a safe sleeping environment?

\section{Materials and Methods}

\section{Design and Participants}

This descriptive, cross-sectional study was conducted at 18 family health centers and 2 hospitals ( 1 public and 1 university hospital) located in the central region of Turkey. The study included 220 midwives and nurses who worked at family health centers and at the gynecology, neonatal, and pediatric clinics of the hospitals between May 06 and July 31, 2019.

\section{Setting}

Data were collected using a descriptive characteristics form and a safe sleep information form created by the investigator. The descriptive characteristics form comprised 7 questions about age, gender, occupation, education level, institution, and unit that the participant worked at as well as years of employment in the job and at the unit. The safe sleep information form comprised 13 questions that could be answered with "yes/no/i don't know" or "true/false/i don't know" to determine the level of knowledge about safe sleep in accordance with the relevant literature $(13,14,16)$. The investigator explained the purpose of the study before administering the questionnaires and filled in the forms within 5-10 min through face-to-face interviews with the participants.

\section{Ethical Approval}

Study approval was obtained from the ethics committee of a university (dated 17.04.2019 and numbered 2019-04/36) and from hospitals and family health centers. Moreover, written and verbal consents were obtained from the midwives and nurses.

\section{Statistical Analysis}

Data obtained in the study were evaluated using the SPSS for Windows Version 22.00 (IBM Corporation, Armonk, New York, USA). Furthermore, data were expressed as percentages (\%) and mean \pm standard deviation values and analyzed using chisquare test, a parametric test. A p-value $<0.05$ was considered statistically significant.

\section{Results}

Descriptive characteristics of the midwives and nurses who participated in the study are shown in Table 1 . The mean participant age was $31.83 \pm 7.63$ years, and $97.7 \%$ of the participants were female. Furthermore, $68.2 \%$ participants were nurses and $31.8 \%$ were midwives, $58.2 \%$ participants had a bachelor's degree. Of all, 56.8\% participants worked at a hospital and $28.2 \%$ at a pediatric clinic; moreover, $60.5 \%$ and $88.2 \%$ of the participants had been working for $0-10$ years in their profession and at the current unit, respectively.

Of all the midwives and nurses, $83.2 \%$ stated that they previously heard about SIDS (31.4\% had heard about it during vocational education), $62.3 \%$ stated that they informed mothers about the safe sleeping environment, $81.8 \%$ stated that the safest sleeping position was the side position, and $94.5 \%$ stated that the baby should sleep on a firm bed. Of all the participants, $99.1 \%$ did not recommend covering the head or face of the baby while sleeping, $90.5 \%$ did not recommend bed-sharing, $94.1 \%$ did not recommend the use of pacifiers, and $65.5 \%$ did not recommend the use of pillows. Furthermore, $86.8 \%$ of the midwives and nurses stated that leaving soft objects in the baby's bed was dangerous, $90 \%$ stated that sleeping in the supine position led to an increased risk of choking, $73.6 \%$ stated that exposing the baby to cigarette smoke led to an increased risk of SIDS, and $75.5 \%$ stated that sudden infant deaths were associated with the babies' sleeping environment (Table 2).

A significant relationship was found between the education level of the midwives and nurses and having heard about SIDS and providing information about safe sleep and between the occupation of the midwives and nurses and providing information about safe sleep $(p<0.05)$. Furthermore, the number of nurses who had previously heard about SIDS and 
informed families about safe sleep was higher among those who had a bachelor's degree (Table 3).

\section{Discussion}

Knowledge and opinions of healthcare professionals about safe sleep play an important role in reducing the risk of sudden death in infants. This study is one of the few studies that have investigated the knowledge and opinions about a safe sleep environment among healthcare professionals working in the field of maternal and child health in Turkey. One of the most important findings of this study was that the majority (81.8\%) of the midwives and nurses stated that the safest sleeping position was the side position. Similar to this, previous studies conducted in Turkey have reported that most of the healthcare professionals recommend sleeping on the side $(13,14)$. AAP (2016) recommends that babies sleep in the supine position; it initiated a campaign for putting babies to sleep in the supine position in 1994. Unlike Turkey, in other countries, studies have shown that the number of healthcare professionals recommending the supine position is higher than that observed

\begin{tabular}{|c|c|c|}
\hline Descriptive characteristics & $\mathbf{n}$ & $\%$ \\
\hline \multicolumn{3}{|l|}{ Age: $31.83 \pm 7.63$} \\
\hline \multicolumn{3}{|l|}{ Gender } \\
\hline Female & 215 & 97.7 \\
\hline Male & 5 & 2.3 \\
\hline \multicolumn{3}{|l|}{ Occupation } \\
\hline Midwife & 70 & 31.8 \\
\hline Nurse & 150 & 68.2 \\
\hline \multicolumn{3}{|l|}{ Education level } \\
\hline Vocational school of health & 39 & 17.7 \\
\hline Associate degree & 33 & 15 \\
\hline Bachelor's degree & 128 & 58.2 \\
\hline Postgraduate & 20 & 9.1 \\
\hline \multicolumn{3}{|l|}{ Place of employment } \\
\hline Hospital & 125 & 56.8 \\
\hline Family health center & 95 & 43.2 \\
\hline \multicolumn{3}{|c|}{ Clinic of employment at the hospital } \\
\hline Pediatric & 62 & 28.2 \\
\hline Gynecology & 10 & 4.5 \\
\hline Neonatal & 52 & 24.1 \\
\hline \multicolumn{3}{|c|}{ Duration of employment in the profession (years) } \\
\hline $0-10$ & 133 & 60.5 \\
\hline $11-20$ & 55 & 25 \\
\hline $21-30$ & 32 & 14.5 \\
\hline \multicolumn{3}{|c|}{ Duration of employment at the current unit (years) } \\
\hline $0-10$ & 194 & 88.2 \\
\hline $11-20$ & 21 & 9.5 \\
\hline $21-30$ & 5 & 2.3 \\
\hline
\end{tabular}

Table 2. Knowledge and opinions of the midwives and nurses about safe sleep ( $n, \%)$

Have you heard of sudden infant death syndrome?

\begin{tabular}{|c|c|c|}
\hline Yes & 183 & 83.2 \\
\hline No & 37 & 16.8 \\
\hline \multicolumn{3}{|c|}{ Where did you hear about SIDS? } \\
\hline At the unit I work at & 47 & 21.4 \\
\hline Vocational education (school) & 69 & 31.4 \\
\hline In-service training & 47 & 21.4 \\
\hline Other (internet, people) & 14 & 6.4 \\
\hline Non-responders & 43 & 19.5 \\
\hline
\end{tabular}

Do you provide mothers with information about the sleeping environment of babies?

\begin{tabular}{|l|l|l|}
\hline Yes & 137 & 62.3 \\
\hline No & 17 & 7.7 \\
\hline Sometimes & 66 & 30 \\
\hline What is the safest sleeping position for babies? \\
\hline Side position & 180 & 81.8 \\
\hline Supine position & 22 & 10 \\
\hline Prone position & 18 & 8.2 \\
\hline How should the baby's bed be? & \multicolumn{2}{|l|}{} \\
\hline Firm/not sinking & 208 & 94.5 \\
\hline Soft/sinking & 12 & 5.5 \\
\hline $\begin{array}{l}\text { Do you recommend using a pacifier when putting the baby to } \\
\text { sleep? }\end{array}$ & 13 & 5.9 \\
\hline Yes & 207 & 94.1 \\
\hline No & \multicolumn{2}{|l|}{} \\
\hline
\end{tabular}

Do you recommend covering the face of the baby while sleeping?

\begin{tabular}{|l|l|l|}
\hline Yes & 2 & 0.9 \\
\hline No & 218 & 99.1 \\
\hline
\end{tabular}

Do you recommend that mothers and babies share bed?

\begin{tabular}{|l|l|l|}
\hline Yes & 21 & 9.5 \\
\hline No & 199 & 90.5 \\
\hline
\end{tabular}

Do you recommend using a pillow for the baby?

\begin{tabular}{|l|l|l|}
\hline Yes & 76 & 34.5 \\
\hline No & 144 & 65.5 \\
\hline \multicolumn{2}{|l|}{ It is dangerous to leave soft objects in the baby's bed } \\
\hline True & 191 & 86.8 \\
\hline False & 29 & 13.2 \\
\hline \multicolumn{4}{|l|}{}
\end{tabular}

The risk of choking is high in babies sleeping in supine position

\begin{tabular}{|l|l|l|}
\hline True & 198 & 90 \\
\hline False & 22 & 10 \\
\hline
\end{tabular}

Exposure of the baby to cigarette smoke during pregnancy and/ or after birth leads to an increased risk of SIDS

\begin{tabular}{|l|l|l|}
\hline True & 162 & 73.6 \\
\hline False & 9 & 4.1 \\
\hline I don't know & 49 & 22.3 \\
\hline $\begin{array}{l}\text { Sudden infant deaths are associated with the sleeping } \\
\text { environment }\end{array}$ & 166 & 75.5 \\
\hline True & 16 & 7.3 \\
\hline False & 38 & 17.3 \\
\hline I don't know & \multicolumn{2}{l}{} \\
\hline SIDS: Sudden Infant Death syndrome &
\end{tabular}




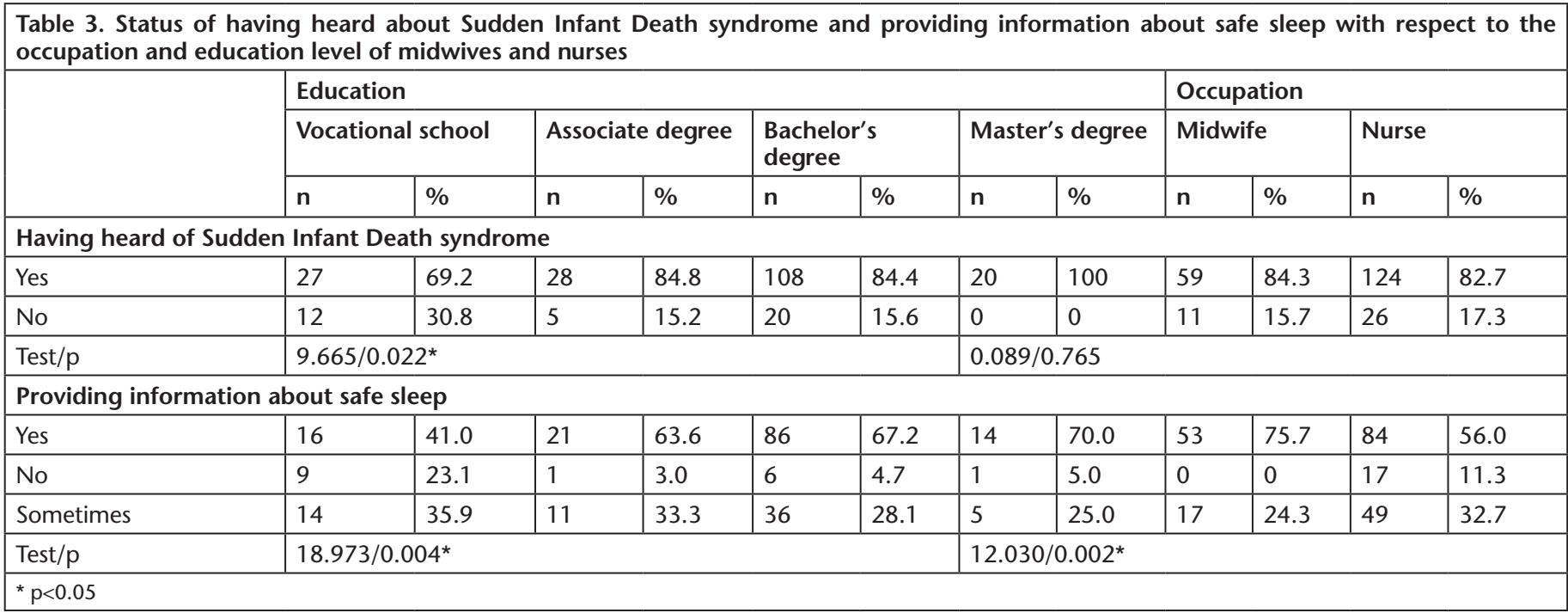

in this study; this is due to the impact of AAP recommendations and campaigns promoting the supine position (16-20). The fact that Turkish healthcare professionals continue to recommend the side position can be linked to the fear of aspiration because the majority of midwives and nurses in the present study stated that the supine position led to an increased risk of choking. Similarly, Efe et al. (13) found that nurses and pediatricians recommended the side position due to the fear of aspiration. In the literature, it can be observed that one of the reasons why nurses did not follow the safe sleep guidelines was the risk of aspiration, and therefore, the side position was still commonly preferred (21). Results of an observational study by McMullen et al. (9) have shown that nurses continue to put babies to sleep in other positions, although they are aware that the supine position is the safest position. Other studies have also shown that nurses do not recommend the supine position due to the fear of aspiration (20-24). The first step toward increasing the rate of putting babies to sleep in the supine position in Turkey should be to persuade healthcare professionals that sleeping in the supine position would not lead to choking.

Avoiding soft surfaces and not leaving soft objects and pillows on the baby's bed are recommended for a safe sleep (1). In this study, most of the midwives and nurses did not recommend using soft beds, leaving soft objects on the baby's bed, and covering the baby's face while asleep. Only one-third of the nurses did not recommend using pillows. Covering the baby's face for protection from environmental danger as well as using pillows and soft objects to ensure that the baby is comfortable and does not fall down from the bed could cause the baby to choke or be trapped. The fact that most of the midwives and nurses did not recommend these could be considered favorable in terms of their knowledge about these risk factors. Previous studies have also shown similar results $(13,16)$.

Bed-sharing, which is one of the risk factors for SIDS, is preferred due to various reasons such as ease of breastfeeding and bonding $(25,26)$. In this study, the majority of the midwives and nurses did not recommend bed-sharing. Similarly, Efe et al.
(13) found that nurses and pediatricians did not recommend bed-sharing. In another study, it was found that pediatricians did not provide any recommendations on bed-sharing or their recommendations varied significantly (27).

It has been reported that breastfeeding and using pacifiers have a role in protection against SIDS. It is recommended to offer a pacifier to the baby before sleep after an effective breastfeeding session $(28,29)$. On the other hand, the "Baby-friendly Hospital" initiative, aiming to cherish and support breastfeeding, and "10 steps to successful breastfeeding" do not recommend offering feeding bottles or pacifiers to breastfed babies (30). In Turkey, pacifiers are not recommended at family health centers and hospitals in accordance with these principles. The fact that the majority of nurses and midwives (90.5\%) in this study did not recommend pacifiers is also possibly associated with these principles. The number of midwives and nurses who recommended the use of pacifiers was higher in another study than in the present study (16).

AAP (2016) recommends avoiding prenatal and environmental exposure of infants to cigarette smoke, which is one of the major risk factors for SIDS. In this study, $73.6 \%$ of the midwives and nurses stated that infant exposure to cigarette smoke leads to an increased risk of SIDS, whereas $22.3 \%$ did not have any such knowledge. In a study by Hodges et al. (16), the rate of healthcare professionals who knew that infant exposure to cigarette smoke leads to an increased risk of SIDS were higher (97.4\%) than that observed in this study. This reveals that the majority of midwives and nurses have the knowledge about the negative effects of infant exposure to cigarette smoke during pregnancy or after birth, but they may need additional information about the association between this exposure and SIDS.

Missing or incorrect knowledge of healthcare professionals about the safe sleeping environment may directly affect parents. It is recommended that clinicians train mothers/babysitters on the current knowledge and practices concerning safe sleep and serve as a role model (31). Some studies have shown that 
healthcare personnel did not have enough knowledge about the safe sleeping environment (32-34) and that serving as a wrong model during nursing care at the hospital had a negative impact on parents' adherence to the recommendations concerning safe sleep $(8,18,24,35)$. In this study, nearly $75 \%-80 \%$ of the midwives and nurses stated that they had knowledge about SIDS and safe sleeping environment. In a study by Hodges et al. (16) it was found that midwives and nurses had a moderate level of knowledge about safe sleep. The present study finding that the majority of midwives and nurses had knowledge should be interpreted carefully because training on safe sleep is not provided to healthcare professionals in Turkey. Therefore, they may actually have limited information with a limited scope. In this study, more than half of the midwives and nurses stated that they provided mothers with information about a safe sleeping environment. The rates of providing information about safe sleep and SIDS to parents before discharge were higher in some studies including neonatal nurses than in the present study $(8,17,36)$. According to another study, the majority of midwives and nurses supported training on a safe sleeping environment in the prenatal period (16); the study showed that the rate of nurses who provided information about safe sleep was higher and the rate of having knowledge and providing information about SIDS and safe sleep increased in parallel with the education level of the midwives and nurses. Grazel et al. (8) reported that deaths associated with SIDS could be decreased by providing adequate training for nurses. In the past, nursing and midwifery education in Turkey was provided in vocational schools of health as well as at associate and undergraduate levels. Currently, those who graduate from a vocational school of health become nursing/midwifery assistants and an associate degree is not granted. Curriculums of undergraduate and postgraduate studies provide some information about SIDS and safe sleep. However, the scope of provision of this information in vocational education and in in-service trainings can be extended further.

\section{Conclusion}

It was found that most of the midwives and nurses did not recommend the supine position for sleeping as they believed it could lead to choking and had knowledge of the risk factors such as bed-sharing, using soft beds, placing soft objects on beds, and exposing infants to cigarette smoke. We recommended including courses about safe sleep and SIDS in curriculums, increasing awareness among midwives and nurses working in the field of maternal and child health, providing them with information to compensate for their lack of information, and providing them with regular training on this subject. In addition, policies and practices can be developed to ensure that a safe sleeping environment is created in the healthcare institutions.

\section{Ethics}

Ethics Committee Approval: Study approval was obtained from the ethics committee of a university (dated 17.04.2019 and numbered 2019-04/36) and from hospitals and family health centers.

Informed Consent: Written and verbal consents were obtained from the midwives and nurses.

Peer-review: Internally peer-reviewed.

Financial Disclosure: The author declared that this study received no financial support.

\section{References}

1. Moon RY, Task Force on Sudden Infant Death Syndrome, AAP Task Force on Sudden Infant Death Syndrome. SIDS and other sleep-related infant deaths: Evidence base for 2016 updated recommendations for a safe infant sleeping environment. Pediatrics 2016;138:1-21.

2. Centers for Disease Control and Prevention (CDC). (2017). Sudden unexpected infant death and sudden infant death syndrome: Data and Statistics. Last Accessed Date: 21.09.2020. Available from: https://www.cdc.gov/sids/data.htm

3. Bebek Ölüm Hızı. (2018). Last Accessed Date: 24.09.2020. Available from: https://hsgm.saglik.gov.tr/depo/birimler/cocuk_ergen_db/ dokumanlar/istatistikler/bebek_cocuk_olumleri_2018.pdf/

4. Healthy People 2020. Morbidity and Mortality. (2002). Last Accessed Date: 15.09.2020.Available from: https://www.healthypeople. gov/2020/topics-objectives/objective/mich-18-0

5. Colson ER, Levenson S, Rybin D, Calianos C, Margolis A, Colton T, Lister G, Corwin MJ. Barriers to following the supine sleep recommendation among mothers at four centers for the women, infants, and children program. Pediatrics 2006;118:e243-50.

6. Flook DM, Vincze DL. Infant safe sleep: Efforts to improve education and awareness. J Pediatr Nurs 2012;27:186-8.

7. Gelfer P, Cameron R, Masters K, Kennedy KA. Integrating "Back to Sleep" recommendations into neonatal ICU practice. Pediatrics 2013;131:e1264-70. doi: 10.1542/peds.2012-1857

8. Grazel R, Phalen AG, Polomano RC. Implementation of the American Academy of Pediatrics recommendations to reduce sudden infant death syndrome risk in neonatal intensive care units: An evaluation of nursing knowledge and practice. Adv Neonatal Care 2010;10:332-42.

9. McMullen SL, Fioravanti ID, Brown K, Carey MG. Safe sleep for hospitalized infants. MCN Am J Matern Child Nurs 2016;41:43-50.

10. Moon RY, Hauck FR, Colson ER. Safe infant sleep interventions: What is the evidence for successful behavior change? Curr Pediatr Rev 2016;12:67-75.

11. Newberry JA. Creating a safe sleep environment for the infant: What the pediatric nurse needs to know. J Pediatr Nurs 2019;44:119-22.

12. Shaefer SJ, Herman SE, Frank SJ, Adkins M, Terhaar M. Translating infant safe sleep evidence into nursing practice. J Obstet Gynecol Neonatal Nurs 2010;39:618-26.

13. Efe E, Inal S, Bal Yılmaz H, Çetin, H, Turan T, Altun E, Calisir H, Arikan D. Nurses' and paediatricians' knowledge about infant sleeping positions and the risk of sudden infant death syndrome in Turkey. Healrhmed 2012;6:140-7.

14. Yikilkan H, Ünalan PC, Çakır E, Ersu RH, Cifcili S, Akman M. Sudden infant death syndrome: How much mothers and health professionals know. Pediatr Int 2011;53:24-8.

15. Mason B, Ahlers-Schmidt CR, Schunn C. Improving safe sleep environments for well newborns in the hospital setting. Clin Pediatr (Phila) 2013;52:969-75.

16. Hodges NL, Anderson SE, McKenzie LB, Katz ML. Certified nursemidwives' knowledge, attitudes, and behaviors about infant safe sleep. J Midwifery Womens Health 2018;63:196-204. 
17. Aris C, Stevens TP, Lemura C, Lipke B, McMullen S, Côté-Arsenault D, Consenstein L. NICU nurses' knowledge and discharge teaching related to infant sleep position and risk of SIDS. Adv Neonatal Care 2006;6:281-94.

18. Bartlow KL, Cartwright SB, Shefferly EK. Nurses' knowledge and adherence to sudden infant death syndrome prevention guidelines. Pediatr Nurs 2016;42:7-13.

19. de Luca F, Gómez-Durán EL, Arimany-Manso J. Paediatricians' practice about sudden infant death syndrome in Catalonia, Spain. Matern Child Health J 2017;21:1267-76.

20. Stastny PF, Ichinose TY, Thayer S, Olson RJ, Keens TG. Infant sleep positioning by nursery staff and mothers in newborn hospital nurseries. Nurs Res 2004;53:122-9.

21. Hitchcock SC. An update on safe infant sleep. Nurs Womens Health 2017;21:307-11.

22. Bullock LF, Mickey K, Green J, Heine A. Are nurses acting as role models for the prevention of SIDS. MCN Am J Matern Child Nurs 2004;29:172-7.

23. Hein HA, Pettit SF. Back to sleep: Good advice for parents but not for hospitals? Pediatrics 2001;107:537-9.

24. Patton C, Stiltner D, Wright KB, Kautz DD. Do nurses provide a safe sleep environment for infants in the hospital setting? An integrative review. Adv Neonatal Care 2015;15:8-22.

25. Ateah CA, Hamelin KJ. Maternal bedsharing practices, experiences, and awareness of risks. J Obstet Gynecol Neonatal Nurs 2008;37:274-81.

26. Duzinski SV, Yuma-Guerrero PJ, Fung A, Brown JM, Wheeler T, Barczyk AN, Lawson KA. Sleep behaviors of infants and young children: Associated demographic and acculturation characteristics among Hispanic teen mothers. J Trauma Nurs 2013;20:189-98.

27. Schaeffer P, Asnes AG. What do pediatricians tell parents about bedsharing? Matern Child Health J 2018;22:51-8.
28. Task Force on Sudden Infant Death Syndrome. AAP Task Force on Sudden Infant Death Syndrome. SIDS and other sleep-related infant deaths: Updated 2016 recommendations for a safe infant sleeping environment. Pediatrics 2016;138:e20162938. Doi: doi. org/10.1542/peds.2016-2938.

29. Hauck FR, Thompson JM, Tanabe KO, Moon RY, Vennemann MM. Breastfeeding and reduced risk of sudden infant death syndrome: $\mathrm{A}$ meta-analysis. Pediatrics 2011;128:103-10.

30. World Health Organization (WHO) and UNICEF. Baby-friendly hospital initiative: revised, updated and expanded for integrated care. Section 1. Background and implementation. Geneva, Switzerland: World Health Organization (2009). Last Accessed Date: 21.10.2020. Available from: https://apps.who.int/iris/bitstream/ handle/10665/43593/9789241594967_eng.pdf?sequence=1.

31. Maged M, Rizzolo D. Preventing sudden infant death syndrome and other sleep-related infant deaths. JAAPA 2018;31:25-30.

32. Ahlers-Schmidt CR, Kuhlmann S, Kuhlmann Z, Schunn C, Rosell J. To improve safe-sleep practices, more emphasis should be placed on removing unsafe items from the crib. Clin Pediatr (Phila) 2014;53:1285-7.

33. Chung-Park MS. Knowledge, opinions, and practices of infant sleep position among parents. Mil Med 2012;177:235-9.

34. Issler RM, Marostica PJ, Giugliani ER. Infant sleep position: A randomized clinical trial of an educational intervention in the maternity ward in Porto Alegre, Brazil. Birth 2009;36:115-21.

35. Andreotta J, Hill C, Eley S, Vincent D, Moore JM. Safe sleep practices and discharge planning. J Neonatal Nurs 2015;21:195-9.

36. Barsman SG, Dowling DA, Damato EG, Czeck P. Neonatal nurses' beliefs, knowledge, and practices in relation to sudden infant death syndrome risk-reduction recommendations. Adv Neonatal Care 2015; 15:209-19. 